\title{
PENGEMBANGAN MODEL PEMBELAJARAN KOSAKATA BAHASA JERMAN (WORTSCHATZ) BERDASARKAN MODEL KOMUNIKASI SMCR-BERLO DI SMA NEGERI DI KOTA MAKASSAR
}

\author{
Misnawaty Usman \\ Fakutas Bahasa dan Sastra Universitas Negeri Makassar \\ Email: misnawatyusman@yahoo.co.id
}

\begin{abstract}
ABSTRAK
Penelitian ini bertujuan untuk mendesain perangkat pembelajaran kosa kata bahasa Jerman berdasarkan model komunikasi SMCR-Berlo sebagai alternatif untuk meningkatkan kualitas pendidikan khususnya pengajarab bahasa Jerman di SMA kota Makassar. Permasalahan utama dalam penelitian ini ialah 1) bagaimana mendesain perangkat pembelajaran kosa kata bahasa Jerman yang valid, praktis dan atraktif untuk diterapkan dalam meningkatkan kemampuan kosa kata bahasa Jerman siswa. 2) bagaimana keefektifan perangkat pembelajaran kosa kata berdasarkan model komunikasi SCMR-Berlo ini. Pendekatan yang digunakan dalam kajian ini ialah penelitian pengembangan. Luaran dari penelitian ini terdiri atas materi pengajaran yang didesain berdasarkan model komunikasi SCMR-Berlo.
\end{abstract}

Kata Kunci: Perangkat Pembelajaran, Kosa Kata, Model Komunikasi SCMR-Berlo

\section{ASBTRACT}

This study aims to design the German language vocabulary learning tools with regard to the communication model SMCR- Berlo, as alternative to improve the quality of education, especially in teaching German language in SMA at Makassar. The Main problem in this research are: firstly, how to design the German language vocabulary learning tools are valid, practical, and attractive to be applied to improve the mastery of vocabulary German in high school students in the city of Makassar State. secondly how the effectiveness of the German language vocabulary learning tool based communication model SMCR-Berlo. The approach used in this research is descriptive analysis approach, while the type of research is research and development ( $\mathrm{R} \& \mathrm{D})$. Expected outcomes are the learning device comprising: first, teaching materials were designed based on the stages in the development of SMCR-Berlo communication model.

Keywords : Learning tools , Vocabulary (wortschatz), SMCR - Berlo Communication Model

\section{PENDAHULUAN}

Di Indonesia bahasa Jerman telah terpilih sebagai salah satu bahasa asing yang diajarkan di sekolah menengah atas (SMA),
Sekolah Menengah Kejuruan dan Madrasah Aliah (MA), dan fokus pengajaran bahasa Jerman ditempatkan pada komunikasi. Penguasaan bahasa Jerman mencakup empat 
aspek keterampilan berbahasa, yakni menyimak (Hörverstehen), berbicara (Sprechfertigkeit), membaca (Leseverstehen) dan menulis (Schreibfertigkeit). Keempat keterampilan bahasa tersebut merupakan satu kesatuan yang tidak dapat dipisahkan satu sama lain. Selain keempat aspek tersebut, terdapat dua kemampuan yakni penguasaan kosakata (Wortschatz) dan tatabahasa (Strukturen/Grammatik). Hal tersebut sesuai dengan standar isi dan standar kompetensi yang termuat dalam kurikulum untuk mata pelajaran bahasa Jerman di SMA, SMK dan MA. Penelitian ini bertujuan untuk mengembangkan perangkat pembelajaran kosakata bahasa Jerman (Wortschatz) dengan berdasar pada model komunikasi SMCR-Berlo, sebagai salah satu alternatif dalam upaya meningkatkan mutu pendidikan khususnya dalam pengajaran bahasa Jerman di SMA Negeri se kota Makassar. Pentingnya penguasaan kosakata bahasa Jerman jika dihubungkan dengan kondisi riilnya masih jauh dari harapan. Seperti hasil temuan Rahman (2002) bahwa penguasan kosakata bahasa Jerman siswa SMA Negeri 5 Makassar rendah dengan nilai rata-rata $52,04 \%$. Hal yang sama dikemukakan pula oleh Rengur (2004) bahwa penguasaan kosakata (Wortschatz) siswa SMA Negeri 2 Takalar tergolong rendah $(48,25 \%)$. Demikian pula hasil penelitian yang dilakukan Adris (2011) di SMA Negeri 10 Makassar menunjukkan bahwa $58 \%$ siswa yang belum dapat mencapai nilai ketuntasan minimal dalam penguasaan kosakata bahasa Jerman, dan oleh Syukri (2007) menyimpulkan bahwa nilai rata-rata yang diperoleh siswa dalam penguasaan kosakata hanya $51,17 \%$. Penelitian tentang rendahnya penguasaan kosakata bahasa Jerman siswa telah dilakukan oleh Septira (2011) pada siswa SMA negeri 8 Makassar, hasil penelitiannya menunjukkan bahwa kemampuan menyimak bahasa Jerman siswa masih rendah yakni 48,25 \%. Dalam penelitian tersebut dinyatakan bahwa faktor penyebab rendahnya kemampuan menyimak bahasa Jerman siswa disebabkan oleh rendahnya penguasaan kosakata bahasa Jerman. Berdasarkan beberaapa hasil penelitian yang telah dikemukakan di atas, dapat disimpulkan bahwa rendahnya keterampilan berbahasa Jerman siswa SMA dan sederajat disebabkan oleh kurangnya penguasaan kosakata bahasa Jerman (wortschatz) mereka.

\section{METODE PENELITIAN}

Pendekatan penelitian yang akan digunakan dalam rencana penelitian ini adalah pendekatan yang bersifat deskriptif analisis, sedangkan jenis penelitiannya termasuk jenis penelitian dan pengembangan dengan mengacu pada model pengembangan perangkat pembelajaran 4-D dari Thiagarajan, Semmel dan Semmel (Thiagarajan, 1974) yaitu pendefinisian (Define), perancangan (Design), pengembangan (Develop), dan penyebaran (Disseminate).

Subyek penelitian ini adalah siswa SMA Negeri 11 Makassar. Penelitian ini bersifat eksperimental maka kelas dipilih secara random dari 10 kelas XI yang ada di SMA Negeri 11 Makassar dan selanjutnya untuk menentukan kelas kontrol dan kelas eksperimen digunakan teknik random. Model pembelajaran dalam penelitian ini adalah suatu kerangka konseptual yang melukiskan prosedur secara sistematis dalam mengorganisasikan pengalaman belajar untuk 
mencapai tujuan tertentu dan berfungsi sebagai pedoman bagi perancang pembelajaran dan para pengajar dalam merencanakan aktivitas belajar mengajar. Kosakata adalah kumpulan kata yang dimiliki ataupun digunakan seseorang dalam berbahasa untuk menyampaikan ide, gagasan dan perasaan baik sebagai pembicara, pendengar, penulis, maupun sebagai pembaca.

Model komunikasi SMCR Berlo adalah singkatan dari Source (S) Message (M), Channel (C) dan Receicer (R). Model SMCR ini jika disesuaikan dalam proses pembelajaran , maka Source-nya adalah materi pembelajaran yang akan diajarkan oleh guru. Message adalah bagaimana guru menyampaikan atau mengkomunikasikan materi pelajaran pada saat berlangsungnya proses pembelajaran di kelas. Channel adalah media yang digunakan dalam proses pembelajaran, sedangkan Receiver adalah siswa sebagai sasaran didik. Model komunikasi SMCR-Berlo.

Instrumen penelitian yang akan digunakan dalam penelitian ini adalah: 1) perangkat tes, 2) Lembar Observasi Aktivitas Guru, 3) Lembar Observasi Aktivitas Siswa, 4) Angket Respon Guru , 5) Angket Respon Siswa, dan 6) Catatan Peneliti. Data yang diperoleh berdasarkan model yang dikembangkan oleh peneliti, bertujuan untuk menganalisis keefektivan model. Analis data yang dilakukan dalam penelitian ini adalah untuk merevisi perangkat pembelajaran dari draf awal hingga draf akhir dengan menganalisis: 1) data validasi pakar, 2) aktivitas siswa, 3) kemampuan guru mengelola pembelajaran, 4) keterlaksanaan perangkat pembelajaran, 5) penguasaan siswa terhadap materi ajar.

\section{HASIL DAN PEMBAHASAN}

Prosedur desain perangkat pembelajaran kosakata (Wortschatz) bahasa Jerman berdasarkan model komunikasi SMCRBerlo dengan menggunakan perangkat pembelajaran model pengembangan dari Thiagarajan. Model ini dikenal dengan model 4-D (four $D$ models) dari Thiagarajan, Semmel dan Semmel (Thiagarajan, 1974) dengan urutan: tahap pendefinisian (Define), tahap perancangan (Design), tahap pengembangan (Develop), dan tahap penyebaran (Disseminate). Selanjutnya, hasil desain perangkat pembelajaran diuraikan sebagai berikut:

\section{Hasil Tahap Pendefinisian (Define)}

Tahap pendefinisian ditetapkan terlebih dahulu sebagai landasan dalam penyusunan rancangan perangkat pembelajaran. Hasil setiap kegiatan pada tahap pendefinisian diurakan sebagai berikut:

a. Hasil Analisis Awal Akhir (Front-end analysis)

Berdasarkan hasil diskusi dengan guru bahasa Jerman di SMA Negeri 11 Makassar tentang kegiatan pembelajaran bahasa Jerman di sekolah tersebut, diperoleh informasi bahwa guru menerapkan pembelajaran bahasa Jerman masih konvensional, kurangnya buku-buku materi pelajaran bahasa Jerman baik yang bersifat buku wajib maupun buku penunjang, minimnya pemahaman tentang metodemetode pembelajaran bahasa yang up to date dan relevan dengan materi ajar, kurangnya media inovatif serta masih langkahnya penerapan model-model pembelajaran yang baik sehingga interaksi dalam proses pembelajaran bahasa Jerman khususnya 
dalam pembelajaran kosakata tidak berjalan secara maksimal.

b. Hasil Analisis Materi

Kegiatan yang dilakukan pada langkah ini adalah mengidentifikasi, merinci, dan menyusun secara sistematis materi-materi utama yang dipelajari siswa, selanjutnya materi tersebut disusun secara hierarkis. Materi pelajaran dalam penelitian ini adalah materi "die Familie" sesuai dengan standar isi.

c. Hasil Analisis Tugas

Hasil analisis tugas tentang materi die Famile (Keluarga) pada penelitian ini sebagai berikut:

1) Menulis kosakata dengan tepat tentang subtema Familien in Indonesia und Deutschland.

2) Melengkapi kalimat dengan kosakata tentang sub tema Familie in Indonesian und in Deutschland.

3) Mengisi dan melengkapi kalimat yang ada dalam tabel dengan kosakata yang sesuai.

4) Menceritakan kembali sesuai contoh tentang keluarga Boris, Monika, Ai, dan Tami.

5) Menentukan kosakata yang tepat sesuai konteks subtema Familie in Indonesian und in Deutschland.

6) Menulis kalimat dengan menggunakan kosakata Familienstammbaum.

7) Menirukan bersama-sama kalimat tentang Familienstammbaum.

8) Menentukan penggunaan possessivepronomen dengan tepat.

d. Hasil Analisis Spesifikasi Tujuan Pembelajaran

Langkah ini dilakukan untuk mengkonversi hasil analisis materi yang dinyatakan dalam bentuk tingkah laku siswa menjadi tujuan pembelajaran. Tujuan ini selanjutnya menjadi dasar untuk penyusunan teks dan merancang perangkat pembelajaran.

1) Kompetensi Dasar

a) Menulis kata, frasa dan kalimat dengan huruf, ejaan dan tanda baca yang tepat.

b) Mengungkapkan informasi secara tertulis dalam kalimat sederhana sesuai konteks yang mencerminkan kecakapan menggunakan kata, frasa dengan huruf, ejaan, tanda baca dan struktur yang tepat.

2) Indikator Pencapaian Hasil Belajar

a) Siswa mampu menulis kata dengan tepat tentang subtema Familie in Indonesian und in Deutschland

b) Siswa mampu menulis dialog sederhana tentang subtema Familie in Indonesian und in Deutschland

c) Siswa mampu menulis frasa/kalimat dengan tepat tentang subtema Familie in Indonesian und in Deutschland.

d) Siswa mampu menentukan kosakata yang tepat sesuai konteks subtema Familie in Indonesian und in Deutschland.

e) Siswa mampu menulis dialog sederhana tentang subtema tentang Familienstammbaum.

f) Siswa mampu menentukan penggunaan possessivepronomen yang tepat.

\section{Hasil Tahap Perancangan (Design)}

Tahap ini bertujuan merancang prototipe perangkat pembelajaran. Hasil pada tahap perancangan (design) berupa empat buah perangkat pembelajaran, yaitu Rencana

Pelaksanaan

Pembelajaran

(Lehrplannvorbereitung), Buku Ajar

(Lehrnbuch), Buku Latihan Siswa (Übungsbuch), Buku Panduan Guru (Lehrhandbuch). Perangkat pembelajaran ini disebut draft awal. Hasil dari masing-masing 
kegiatan pada tahap perancangan diuraikan sebagai berikut:

a. Hasil Pemilihan Media

Pemilihan media dilakukan untuk menentukan media yang tepat dalam penyajian materi pelajaran kosakata bahasa Jerman (Wortschatz). Media yang dimaksudkan dalam penelitian adalah media melalui saluran (channel) baik penglihatan, pendengaran, penciuman, pengecapan maupun perabaan seperti yang terdapat dalam model komunikasi SMCR-Berlo. Sedangkan alat bantu pembelajaran diperlukan meliputi: (1) papan tulis, (2) spidol, (3) penghapus, (4) LCD, (5) Speaker, (6) Laptop, dan sebagainya.

b. Hasil Pemilihan Format

Pemilihan format perangkat pembelajaran bertujuan untuk memilih format untuk mendesain atau merancang perangkat pembelajaran, pemilihan strategi, pendekatan, metode pembelajaran dan sumber belajar. Isi dari perangkat pembelajaran tersebut disusun sesuai dengan prinsip, karakteristik dan langkah-langkah model komunikasi SMCR-Berlo. Secara umum, format perangkat pembelajaran diuraikan sebagai berikut:

1) Rencana Pelaksanaan Pembelajaran (RPP)/Lehrplannvorbereitung

RPP yang dirancang didasarkan pada model komunikasi SMCR-Berlo yang menggambarkan prosedur dan langkahlangkah pengorganisasian pembelajaran untuk mecapai tujuan yang telah ditetapkan.

2) Buku Ajar (Lehrbuch)

Buku Ajar (BA) yang dihasilkan dengan tema die Familie berdasarkan model komunikasi SMCR-Berlo yang menekankan pada channel: hearing, seeing, touching, smelling, dan tasting serta sesuai dengan SK,
KD yang terdiri dari beberapa sub. tema: Familie in Indonesian und in Deutschland, Familiengeschichten, Meinfamilienalbum, der Familienstammbaum, Kleinfamilie und Grossfamilie, Die Leute und Ihre Sache, und Probleme in der Familien.

\section{3) Buku Pegangan Guru (Lehrhandbuch)}

Secara umum, Lehrhandbuch yang dirancang memiliki langkah-langkah penyusunan pada umumnya namun Lehrhandbuch model komunikasi SMCRBerlo dikembangkan secara lebih spesifik pada setiap channel : seeing, hearing, touching, smelling, tasting dengan tahapan: a) Tujuan Belajar, b) Kosakata (Wortschatz), c) Langkah-langkah pembelajaran, d)Tahapan pemahaman, e) Channel, dan d) Tahapan Motivasi.

\section{Hasil Tahap Pengembangan (Develop)}

Tahap pengembangan adalah tahap lanjutan dari tahap pendefinisian dan tahap perancangan dan merupakan tahapan ketiga dari model 4-D (Four-D Models). Tahap pengembangan (develop) bertujuan untuk menghasilkan perangkat pembelajaran yang telah direvisi dan layak untuk diujicobakan. Hasil dari setiap kegiatan pada tahap pengembangan ini diuraikan sebagai berikut.

a. Deskripsi penilaian ahli terhadap perangkat pembelajaran

Penilaian ahli dan praktisi terhadap RPP ((Lehrplannvorbereitung), Buku Latihan Siswa (Übungsbuch), Buku Ajar (Lehrbuch), dan Buku Pegangan Guru (Lehrhandbuch) didasarkan pada: format, bahasa, isi, ilustrasi, dan manfaat/kegunaan yang tertuang dalam instrumen lembar validasi perangkat pembelajaran. 
b. Revisi Rencana Pelaksanaan

Pembelajaran (RPP)

Hasil validasi untuk RPP menunjukkan bahwa para validator umumnya menyimpulkan bahwa RPP yang dikembangkan dinyatakan valid dan dapat digunakan dengan melakukan sedikit revisi.

\section{c. Revisi Buku Latihan Siswa (Übungsbuch)}

Buku Latihan Siswa (Übungsbuch) merupakan komponen yang paling penting di dalam penguasaan kosakata bahasa Jerman siswa. Buku Latihan Siswa (Übungsbuch) ini berisi latihan (Übung) yang dapat dikerjakan siswa secara mandiri ataupun berkelompok selama proses pembelajaran berlangsung. Hasil validasi Buku Latihan Siswa (Übungsbuch) dari para validator umumnya menyimpulkan bahwa Buku Latihan Siswa (Übungsbuch) dinyatakan sudah valid dan dapat digunakan dalam kelas, hanya beberapa bagian yang perlu direvisi antara lain: (1) bahasa; (2) pengaturan tata letak; (3) pemberian contoh untuk setiap tugas yang diberikan; (4) penggunaan istilah; (5) penyamaan jumlah titik-titik dalam soal, dan (6) kesalahan penulisan.

d. Revisi Buku Ajar (Lehrbuch)

Buku Ajar (Lehrbuch) merupakan buku yang digunakan guru yang telah dirancang dalam pengajaran bahasa Jerman khususnya dalam pembelajaran kosakata bahasa Jerman berdasarkan model komunikasi SMCRBerlo. Buku Ajar (Lehrbuch) berisi materi tentang: Familie in Indonesian und in Deutschland, Familiengeschichten, mein Familiealbum, Familie International, Familienfest im Restaurant, Familiestammbaum, 4. Kleinfamilie und Großfamilie, 5. Die Leute und Ihre Sachen, Die Familiengehörige, Probleme in der
Familie.

e. Revisi buku panduan guru (Lehrhandbuch)

Hasil validasi buku panduan guru menunjukkan para validator umumnya menyimpulkan bahwa buku panduan guru sudah valid dan dapat digunakan dengan melakukan sedikit revisi. Kegiatan simulasi dilaksanakan di Kelas XI IPA 1 SMA Negeri 11 Makassar sebanyak 4 kali pertemuan.

Setelah draf awal perangkat pembelajaran direvisi berdasarkan hasil validasi, hasil revisi tersebut kemudian diujicobakan dengan cara menggunakan perangkat pembelajaran tersebut di sekolah tempat uji coba. Tujuan uji coba ini adalah untuk mendapatkan masukan dari siswa dan pengamat.

Kegiatan uji coba perangkat pembelajaran dilaksanakan sehari dalam setiap bulan mulai bulan April sampai dengan bulan Mei 2016 dengan jadwal sebagai berikut: (1) hari senin, tanggal 25 April 2016 dilaksanakan uji coba perangkat pembelajaran tahap pertama dengan durasi waktu selama 90 menit. Uji coba perangkat pembelajaran tahap kedua dilaksanakan pada hari Rabu, tanggal 20 April 2016 dengan durasi waktu yang sama pada tahap pertama. Selanjutnya uji coba perangkat pembelajaran tahap ketiga dilaksanakan pada hari Senin, tanggal 2 Mei 2016 dengan waktu 90 menit. Pada hari terakhir Kamis, tanggal 5 Mei 2016 dilaksanakan pengisian angket tentang respon siswa terhadap model pembelajaran menulis deskripsi bahasa Jerman berdasarkan model komunikasi SMCR-Berlo.

Siswa yang menjadi subjek uji coba perangkat ini adalah siswa kelas XI IPA 1 SMA Negeri 11 Makassar semester ganjil 2015/2016 dengan jumlah siswa sebanyak 
24 orang yang dipilih secara random dari enam kelas.

a. Deskripsi hasil uji coba perangkat pembelajaran

Uji coba dilakukan sebanyak 4 kali pertemuan mulai tanggal 25 April 2016 sampai dengan 5 Mei 2016. Rancangan awal perangkat pembelajaran divalidasi oleh ahli dan praktisi dalam bidang pendidikan bahasa Jerman. Hasil validasi ahli dan praktisi dijadikan sebagai bahan pertimbangan untuk merevisi perangkat pembelajaran. Selanjutnya, berdasarkan hasil simulasi dan uji keterbacaan, perangkat direvisi kembali, kemudian diujicobakan di kelas XI IPA I SMA Negeri 11 Makassar.

b. Analisis kepraktisan (keterlaksanaan) perangkat pembelajaran

Tujuan analisis data keterlaksanaan perangkat pembelajaran adalah untuk melihat tingkat kepraktisan perangkat pembelajaran berdasarkan model komunikasi SMCR-Berlo dalam pengajaran khususnya penguasaan kosakata bahasa Jerman dianalisis per aspek.

1) Komponen Sintaks

Komponen sintaks model pembelajaran kosakata bahasa Jerman berdasarkan model komunikasi SMCR-Berlo secara konkrit dikembangkan terlihat dari langkah-langkah yang ditempuh guru dalam menyampaikan tujuan pembelajaran, memaparkan prosedur pelaksanaan model komunikasi SMCR-Berlo, membimbing eksperimen/penyelidikan untuk mengamati perkembangan kelompok dan memantau perkembangan individu, dan mengembangkan dan menyampaikan ide serta gagasan dalam materi kosakata bahasa Jerman model komunikasi SMCR-Berlo, mengkonfirmasi dan mengevaluasi ide serta gagasan dalam materi kosakata bahasa
Jerman berdasarkan model komunikasi SMCR-Berlo.

2) Interaksi Sosial

Interaksi sosial tersebut meliputi: 1) interaksi siswa dengan siswa, serta siswa dengan guru dalam pembelajaran kosakata bahasa Jerman berdasarkan model komunikasi SMCR-Berlo. 2) keaktifan siswa dalam menganalisis data yang telah dikumpulkan untuk memeroleh solusi yang disajikan dalam BLS (Buku latihan Siswa) model komunikasi SMCR-Berlo. 3) keaktifan siswa dalam belajar khususnya pada saat siswa mengkonstruksi BLS dalam materi kosakata bahasa Jerman berdasarkan model komunikasi SMCR- Berlo. 4) keaktifan siswa mengerjakan soal yang terdapat pada BLS berdasarkan model komunikasi SMCRBerlo.

\section{3) Prinsip Reaksi}

Hasil pengamatan terhadap keterlaksanaan komponen prinsip reaksi selama uji coba menyatakan bahwa pengamatan terhadap penyediaan dan pengelolaan sumber belajar yang trtuang dalam Kompetensi Dasar (KD) sudah dicapai, juga perhitungan rasionalitas alokasi waktu pada setiap pembelajaran dan penyiapan alat bantu pembelajaran sudah terlaksana dengan baik.

c. Uji keefektifan perangkat pembelajaran

Pada bagian sebelumnya, telah dikemukakan hasil uji kevalidan perangkat pembelajaran dan instrumen lainnya. Berikutnya, dideskripsikan hasil uji coba keefektifan. Pada batasan istilah, telah dinyatakan bahwa perangkat pembelajaran efektif apabila memenuhi 3 dari 4 kriteria meliputi: (1) aktivitas siswa selama proses pembelajaran kosakata bahasa Jerman berdasarkan model komunikasi SMCR- 
Berlo, (2) kemampuan guru mengelola pembelajaran dengan model SMCR-Berlo, (3) respon siswa terhadap perangkat pembelajaran, dan (4) ketuntasan hasil belajar.

1) Deskripsi Hasil Aktivitas Siswa Selama Proses Pembelajaran Kosakata Bahasa Jerman Berdasarkan Model Komunikasi SMCR-Berlo.

Secara umum hasil analisis data pengamatan aktivitas siswa menunjukkan bahwa ada beberapa pernyataan positif yang ditanggapi secara positif oleh responden antara lain situasi kelas yang aman untuk melaksanakan Kegiatan Belajar Mengajar (KBM) dengan menggunakan model komunikasi SMCR- Berlo, siswa aktif mengemukakan pendapat dan tanya jawab antara siswa dengan siswa lainnya atau antara siswa dengan gurunya, guru senantiasa menggunakan alat bantu atau media pembelajaran melalui saluran panca indra, materi pembelajaran sangat menarik, dan yang terakhir rasa ingin tahu (neugierig) siswa sangat tinggi.

2) Deskripsi Hasil Pengamatan Kemampuan Guru Mengelola Pembelajaran

Pengamatan terhadap kemampuan guru mengelola pembelajaran menggunakan instrumen lembar observasi pengelolaan pembelajaran. Penilaian pengamatan dilakukan oleh satu orang pengamat terhadap kemampuan guru mengelola pembelajaran kosakata bahasa Jerman berdasarkan model komunikasi SMCR-Berlo.

\section{3) Deskripsi Hasil Respon Siswa}

Instrumen yang digunakan untuk memeroleh data respon siswa adalah angket respon siswa. Angket ini diberikan kepada siswa setelah mengikuti kegiatan pembelajaran dengan menggunakan perangkat pembelajaran berdasarkan model komunikasi SMCR- Berlo dalam pengajaran kosakata bahasa Jerman untuk diisi menurut pendapat mereka terhadap perangkat pembelajaran dan kegiatan pembelajaran.

Berdasarkan hasil analisis data terlihat bahwa respon siswa terhadap pelaksanaan pembelajaran dengan menggunakan perangkat pembelajaran kosakata bahasa Jerman berdasarkan model komunikasi SMCR-Berlo sangat baik. Rata-rata 92,83\% siswa menyatakan senang terhadap perangkat pembelajaran, materi pelajaran, suasana pembelajaran di kelas, dan cara guru mengajar. 86,33\% siswa menyatakan perangkat pembelajaran, materi pelajaran, suasana pembelajaran di kelas, dan cara guru mengajar dianggap baru bagi mereka. $83,72 \%$ siswa menyatakan berminat untuk mengikuti pelajaran seperti yang telah mereka ikuti (pembelajaran kosakata deskripsi bahasa Jerman berdasarkan model komunikasi SMCR-Berlo). 90,67\% siswa menyatakan bahwa kegiatan belajar mengajar dengan menggunakan perangkat pembelajaran berdasarkan model komunikasi SMCR-Berlo menarik dan merasakan ada kemajuan setelah mengikuti proses pembelajaran. $92,67 \%$ siswa menyatakan setuju jika dalam kegiatan belajar mengajar guru menggunakan perangkat pembelajaran berdasarkan model komunikasi SMCR-Berlo. Hasil analisis respon siswa terhadap pelaksanaan pembelajaran kosakata bahasa Jerman berdasarkan model komunikasi SMCRBerlo, Lehrnbuch dan Übungsbuch secara keseluruhan dapat diartikan secara umum terlihat bahwa $92,83 \%$ siswa memberi respon positif terhadap pelaksanaan pembelajaran kosakata bahasa Jerman 
berdasarkan model komunikasi SMCRBerlo, 86,33\% siswa yang memberi respon positif terhadap Kursbuch, dan 83,72\% siswa memberi respon positif terhadap Arbeitbuch.

\section{Deskripsi Hasil Penyebaran}

Perangkat yang dihasilkan pada tahap akhir pengembangan, selanjutnya disebarkan atau disosialisasikan secara terbatas pada guru bahasa Jerman SMA Negeri 11 Makassar.

Pada bagian ini dikembangkan pembahasan hasil penelitian meliputi 4 bagian, yakni: (1) ketercapaian tujuan penelitian, (2) temuan khusus, (3) kendalakendala yang dihadapi, dan (4) perbandingan perangkat pembelajaran konvensional dengan perangkat pembelajaran SMCR-Berlo. Temuan khusus yang dimaksudkan dalam bab ini adalah temuan-temuan yang diperoleh selama pelaksanaan uji coba perangkat pembelajaran kosakata bahasa Jerman berdasarkan model komunikasi SMCRBerlo, khususnya yang terkait dengan kondisi siswa yang menjadi subjek penelitian.

Hasil penilaian ahli dan praktisi dalam bidang pendidikan bahasa Jerman menunjukkan bahwa perangkat pembelajaran kosakata bahasa Jerman berdasarkan model komunikasi SMCRBerlo ditinjau dari keseluruhan aspek dapat dinyatakan valid, meskipun masih terdapat saran-saran perbaikan yang perlu diperhatikan untuk kesempurnaan perangkat yang dikembangkan.

Model pembelajaran kosakata bahasa Jerman dalam pengajarannya dipilih beberapa materi yang sangat terkait. .

a. Komponen Sintaks

Model pembelajaran kosakata bahasa Jerman dilihat dari aspek sintaksnya diklasifikasikan ke dalam beberapa fase pelaksanaanya yang meliputi: 1) menyampaikan tujuan pembelajaran. 2) memaparkan prosedur pelaksanaan model komunikasi SMCR-Berlo. 3) membimbing eksperimen/penyelidikan untuk mengamati perkembangan kelompok dan memantau perkembangan individu. 4) mengembangkan dan menyampaikan ide serta gagasan dalam materi keterampilan menulis deskripsi model komunikasi SMCR-Berlo. 5. mengkonfirmasi dan mengevaluasi ide serta gagasan dalam materi.

\section{b. Sistem Sosial}

Sistem sosial yang dimaksud dalam model pembelajaran kosakata bahasa Jerman berdasarkan model komunikasi SMCR-Berlo yaitu (1) interaksi siswa dengan siswa, serta siswa dengan guru dalam mengerjakan Übungtsbuch (Buku Latihan Siswa) kosakata bahasa Jerman berdasarkan model komunikasi SMCR-Berlo; (2) keaktifan siswa dalam menganalisis data yang telah dikumpulkan untuk memeroleh solusi yang disajikan dalam BLS model komunikasi SMCR-Berlo; (3) keaktifan siswa dalam belajar khususnya pada saat siswa mengkonstruksi BLS kosakata bahasa Jerman model komunikasi SMCR-Berlo; (4) keaktifan siswa mengerjakan soal yang terdapat pada Lehrnbuch dan Übungtsbuch model komunikasi SMCR-Berlo.

c. Prinsip Reaksi

Dampak pengiring yang terpenting secara sadar belum tersentuh oleh guru dalam KBM (Kegiatan Belajar Mengajar). Oleh karena itu, guru dituntut agar mampu merencanakan dan melaksanakan pembelajaran sehingga tercapai secara tuntas tujuan-tujuan pembelajaran. 


\section{d. Aplikasi}

Model pembelajaran kosakata bahasa Jerman berdasarkan model komunikasi SMCR-Berlo dalam aplikasinya kedalam proses pembelajaran meliputi:

1) Berpusat pada Siswa (Student Centre)

Proses pembelajaran kosakata bahasa Jerman berdasarkan model komunikasi SMCR-Berlo ini berpusat pada siswa (Student Centre), hal ini sesuai dengan pendekatan belajar modern yang lebih menempatkan siswa sebagai subjek belajar sedangkan guru berperan sebagai fasilitator yang memberikan kemudahan-kemudahan kepada siswa dan memfasilitasi untuk melakukan aktivitas belajar.

2) Memberikan Pengalaman Langsung

Model pembelajaran ini memberikan pengalaman langsung kepada siswa dalam mengespresikan pengetahuan, pengalaman dan rasa ingin tahu mereka terhadap hal-hal baru yang mereka pelajari. Mereka dihadapkan secara nyata benda-benda sesuai dengan materi yang terkandung dalam buku ajar.

\section{3) Bersifat Fleksibel}

Dalam proses pembelajaran menulis deskripsi bahasa Jerman berdasarkan model komunikasi SMCR-Berlo lebih bersifat fleksibel. Artinya, dalam tema pembelajarannya sangat mungkin dikaitkan dengan kehidupan siswa dan keadaan lingkungan dimana sekolah dan siswa itu berada.

4) Menggunakan prinsip belajar sambil bermain dan menyenangkan

Model pembelajaran ini dalam pelaksanaannya mengadopsi prinsip belajar PAKEM yaitu pembelajaran aktif, kreatif, efektif, dan menyenangkan. Pembelajaran Aktif artinya siswa dalam proses pembelajarannya aktif baik secara fisik maupun mental mengemukakan penalaran tentang materi yang diajarkan, menghubungkan kaitan yang satu dengan yang lain, dan aktif dalam mengemukakan pendapat.

e. Sistem Pendukung

Sistem pendukung dalam model pembelajaran kosakata bahasa Jerman berdasarkan model komunikasi SMCR-Berlo berkaitan dengan sarana dan prasarana. Guru dalam pelaksanaan model pembelajaran kosakata bahasa Jerman berdasarkan model komunikasi SMCR-Berlo, harus cermat memilih media yang akan digunakan. Tidak mudah merancang model komunikasi SMCR-Berlo yang sesuai dengan subtema yang dibahas dan diintegrasikan dalam pengajaran kosakata bahasa Jerman..

Melihat perbandingan antara perangkat pembelajaran yang selama ini dilaksanakan oleh para pengajar di Sekolah Menengah Atas atau di Madrasah Aliyah Negeri dengan perangkat pembelajaran khususnya pembelajaran menulis deskripsi bahasa Jerman berdasarkan SMCR-Berlo sebagai berikut:

a. Perangkat Pembelajaran Rencana Pelaksanaan Pembelajaran (RPP).

Ditinjau dari segi format yang meliputi kejelasan pembagian materi, sistem penomoran, pengaturan ruang dan tata letak serta penyesuaian jenis dan ukuran huruf, masing-masing model baik model pembelajaran konvensional maupun model SMCR-Berlo menganggap indikatorindikator tersebut masih perlu dipertahankan.

b. Perangkat Pembelajaran Buku Ajar (Lehrnbuch)

Buku ajar ditinjau dari segi format mengenai pembagian materi dan sistem 
penomoran dinyatakan sudah jelas dan tidak ada perbedaan antara buku ajar yang konvensional dengan buku ajar yang didesain berdasarkan model komunikasi SMCR-Berlo, tetapi indikator tentang daya ketertarikan, kesesuain antara teks dan ilustrasi, dan pengaturan ruang/tata letak buku ajar berdasarkan model komunikasi SMCR-Berlo dianggap lebih lengkap. Buku ajar konvensional sesuai standar isi KTSP sedangkan buku ajar SMCR-Berlo disamping masih sesuai standar isi KTSP, juga sudah mulai mengarah ke standar isi kurikulum 2013.

\section{c. Perangkat Buku Panduan Guru (Lehrhandbuch)}

Hampir tidak ada perbedaan buku panduan guru baik konvensional maupun buku panduan guru model komunikasi SMCR-Berlo bila ditinjau dari tujuan, alokasi waktu, maupun alternatif penyelesaian soal, hanya dalam pengembangan materi pembelajaran dan aktivitas siswa sedikit berbeda. Format buku panduan guru baik dalam kejelasan pembagian materi, penomoran maupun jenis dan ukuran huruf tidak ada perbedaan. Hanya pada keseimbangan antara teks dan ilustrasi pada buku panduan guru model komunikasi SMCR-Berlo karena formatnya lebih menarik dan variatif. Selanjutnya, isi buku panduan guru masing-masing telah sesuai dengan KTSP, sudah sesuai konsep dan materi, urutan materi, dan keajegan penggunaan istilah.

\section{d. Buku Latihan Siswa (Übungsbuch)}

Format perbandingan antara perangkat pembelajaran buku latihan siswa konvensional dengan SMCR-Berlo hampir tidak ada perbedaan, baik pada kejelasan pembagian materi, sistem penomoran, pengaturan ruang/tata letak, dan jenis dan ukuran huruf serta antara fisik buku dan siswa telah sesuai, hanya perangkat pembelajaran buku latihan siswa model komunikasi SMCR-Berlo yang mempunyai daya tarik tersendiri.

Hal khusus yang ditemukan dalam penelitian ini adalah kemampuan siswa dalam menuangkan ide, pikiran, ataupun pendapat baik lisan maupun tulisan disajikan dengan cukup baik dan termasuk kategori "befridigend" pada latihan uji kompetensi maupun pada tes hasil belajar. Siswa menggunakan model komunikasi SMCRBerlo dalam berlatih mengembangkan kompetensi berbahasa meliputi mendengan (hören), berbicara (sprechen), membaca (lesen), dan menulis (schreiben).

\section{KESIMPULAN}

1. Rencana Pelaksanaan Pembelajaran (RPP)/Unterrichtsplan yang dikembangkan memuat komponenkomponen berikut: standar kompetensi, kompetensi dasar, indikator pencapaian, tujuan pembelajaran, materi pembelajaran model komunikasi SMCRBerlo. Aspek panca indera sebagai ciri khas dalam model komunikasi SMCRBerlo secara jelas tertera di dalam setiap indikator rencana pelaksanaan pembelajaran kosakata bahasa Jerman.

2. Buku latihan siswa (Übungsbuch) yang dikembangkan dalam pembelajaran kosakata bahasa Jerman berdasarkan model komunikasi SMCR-Berlo untuk materi disajikan dengan menggunakan channel: seeing, hearing, touching, smelling, tasting. .

3. Buku Ajar (Lehrnbuch) dirancang berdasarkan model komunikasi SMCR- 
Berlo berisi petunjuk-petunjuk yang disertai ruang kosong sebagai tempat bagi siswa untuk menuliskan jawaban mereka sebagai penyelesaian dari setiap masalah kontekstual yang diberikan.

4. Buku Panduan Guru yang dikembangkan adalah berupa buku petunjuk, di mana guru memberikan cara menggunakan buku pegangan siswa, sehingga siswa mudah memahami dan mampu menggunakan buku tersebut. Buku panduan guru ini, dalam pelaksanaan pembelajaran di kelas merupakan acuan dari materi yang dibahas dan dikembangkan secara lebih spesifik pada setiap channel: seeing, hearing, touching, smelling, tasting.

\section{DAFTAR PUSTAKA}

Ammon, Ulrich. 1991. De Internationale Stellung der deutschen Sprache. Berlin: Walter der Gruyter \& Co.

Berlo, K. David. 1960. The process of Communication. Holt. Rinehart and Winston Inc. New York. NY.

Briggs, Lisslie, 1978. Instructional Design, New Jersey : Ed.Techn Pub.

Dahar, Ratna Wiliis. 2007. Teori-Teori Belajar. Jakarta: Erlangga.

Depdiknas. 2003. Kurikulum 2004 Standar Kompetensi Mata Pelajaran Bahasa Jerman. Jakarta. Depdiknas

Djiwandono, M. Soenardi. 2008. Tes Bahasa: Pegangan Bagi Pengajar Bahasa. Jakarta: PT. Mancanan Jaya Cemerlang.

Drowdowski, Günther. 2003. Deutsher Universal Wörterbuch.

Bibliografischer Insstitut Mannheim. Wien Zurich. Duden Verlag.
Dryden, Gordon \& Jeannet Vos. 2001. The Learning Revolution I; Keajaiban Pikiran. Bandung, Kaifa.

Duden. 2007. Duden Deutsches Universal Wörterbuch. Mannheim: Dudenverlag.

Fisher., B. Aubrey, 2007, Interpersonal Communication: Pragmatics of Human Relation 2 nd ed., McGrawHill

Gagne, RM, Briggs, LJ, \& Taruhan, WW (1992). Principles of instructional design. (Prinsip-prinsip desain instruksional). Fort Worth: Harcourt Brace Jovanovich.Fort Worth: Harcourt Brace Jovanovich.

Gagne M, Robert. Marcy Parkins Driscoll. 1989. Essentials of learning for Instructional. Florida: State University.

Joyce Bruce. Et al. 2000. Models of Teaching. London: allyn Bacon.

Keraf, Geroys. 2000. Diksi dan Gaya Bahasa. Jakarta: Gramedia.

Mulyana, Deddy. 2000. Pengantar Ilmu Komunikasi. Bandung: PT. Remaja Rosdakarya.

Rahmat, Jalaluddin. 2007. Metode Penelitian Komunikasi. Bandung: PT Remaja Rosdakarya.

Rastuti, M.G Hesti Puji. 2009. Ragam Kata Bahasa Indonesia. Surabaya: Jepe Press Media Utama.

Scholl, Stefani. 2007. Führt der Einsatz der Wörtscahtzleiste im

Sprachunterricht. Norderstedt. Germany: GRIN Verlag.

Thiagarajan, S., Semmel, D.S., \& Semmel, M.I. $\quad$ 1974. Introductional Development for Training Teachers of Expectation Children. USA. 
Trianto. 2010. Mengembangkan Model Pembelajaran Tematik. Jakarta: PT. Pustaka Karya.

Pateda, Mansoer. 1995. Kosakata dan Pengajarannya. Ende-Flores, Nusa Indah.

Rahman. 2002. Korelasi antara Penguasaan kosakata Bahasa Jerman dengan Kemampuan Berbicara Siswa SMA Negeri 5 Makassar. Skripsi. UNM.

Rastuti, M.G Hesti Puji. 2009. Ragam Kata Bahasa Indonesia. Surabaya: Jepe Press Media Utama.

Rengur, Santi. 2004. Peningkatan Penguasan Kosakata Bahasa Jerman dengan menggunakan Media Kartu Kata bagi Siswa SMA Negeri 2 Takalar. Skripsi. UNM.

Saud, Syukur dan Misnawaty Usman. 2004. Komunikasi Instruksional dalam Pengajaran Bahasa Jerman Mahasiswa Jurusan Pendidikan Bahasa Asing/Jerman FBS UNM. Laporan Penelitian. Dikti.

Septira, Andi. 2012. Efektivitas Penggunaan Media Audio Visual Terhadap
Peningkatan Keterampilan

Menyimak Bahasa Jerman Siswa SMA Negeri 8 Makassar. Skripsi. FBS-UNM.

Slavin, R.E. 2000. Educational Psychology, Theory and Practice. United State of America: Allyn \& Bacon.

Tarigan, H.G. 2011. Pengajaran Kosakata (Edisi Revisi). Bandung: Angkasa.

Usman, Misnawaty. 2002. Perbandingan Prestasi Belajar Mahasiswa Program Studi Bahasa Jerman FBS UNM yang diajar dengan menggunakan Metode Komunikatif dengan Metode Tradisional dalam Konteks Komunikasi Instruksional. Tesis. UNPAD Bandung.

Werner J. Severin dan James Tankard. 2002. Comm unication Theories: Or igins, Method, and Uses in teh Mass Media. New York: Longman.

Zacharis, John C dan Coleman C. Bender. 2006. Speech Communication: A Rational Approach. New York : John Wiley \& Sons. 